\title{
EXTERNAL FACTORS OF SYSTEM TRANSFORMATION IN POLAND
}

\author{
NATALIIA HOLUBIAK
}

\begin{abstract}
The author analyzed e a new perspective on democratization processes, by analyzing the role of external dynamics in the transformation Poland. The academic research only recently started to focus on the external factors, and the influenced agents were mainly the political elites and institutions. The first part examines the theoretical foundations of transformation, a combination of external and internal factors that have influenced the processes in Central and Eastern Europe. For example, the model, presented by the researcher Edmund Wnuk-Lipiński shows the sequence of five phases of transition from the old system to the new one in Poland. In the next part, author describes "transformation through integration" and analyzes the effect of the overlap of the systemic transformation process on accession processes. In conclusion, membership in the EU is considered as an opportunity to further develop, the factor of increase foreign direct investment and the choice of civilization for Polish society.
\end{abstract}

Keywords: transformation, accession to the EU, integration, "external factors of transformation".

\section{INTRODUCTION}

The transformation period is particularly important for Poland and all of Europe. Thanks to the changes taking place in Central and Eastern Europe, many nations have gained freedom, sovereignty and, therefore the ability to shape the surrounding reality.

After the collapse of communism, East-Central European countries found themselves in differing situations, especially in the economic, political, and social senses. The publicly circulated evaluation of the Polish transformation has always been and still is much diversified. When communist rule collapsed in 1989, Poland differed from the other Soviet Bloc countries in next major respects. The first factor was the strong position of the Catholic Church, symbolized by the pontificate of John Paul II and the communist authorities' conciliatory policy towards the clergy throughout the 1980s. The numerical strength of the democratic opposition made for the next distinction. At the end of the 1980s more than 20,000 people were actively involved. The next difference was the scale of the economic crisis: it was deeper than in the other Soviet Bloc countries and had been deteriorating steadily since the late 1970s [4].

Today it can be argued that there was, and is, no single model of change in post-communist EastCentral Europe. The course of change in fact depended, and still depends, on numerous internal and external premises, e.g., countries' own statehood traditions, democratic traditions, the quality of 
political elites, the ethnic composition of society, the political culture, relations with Western culture, the level of civilizational development, etc. [6, p. 377].

As history shows, the system transformation took place according to a certain pattern, passing subsequent stages. In particular, some researchers defined three types of processes, which contributed to the systemic transformation in Poland, such as global tendencies; general changes in the former communist bloc and changes specific to Polish processes [19, p. 37]. However, their "transformational power", understood as the ability to cause such changes, after which the old system loses the ability to maintain a functional balance.

The aim of our study implies analysis of external factors of democratization in Central and Eastern Europe, especial the impact of EU on the result of Polish transformation. Let us try answering the following questions: What factors were contributed systemic transformation in the countries of Central and Eastern Europe? Why is the European Union important for Poland, especially in the transformation process? Europeanization or transformation, isn't it true? What are the chances of EU membership for Poland?

\section{CONCEPTUAl UNDERSTANDiNG OF “EXTERNAL FACTORS OF TRANSFORMATION"}

What does the term "transformation" mean? This concept relates to political transformations in Latin America in the 1970s - 80s. Democratic transformation was viewed as a transition from authoritarian rule toward democracy. Later on, the historical experience of many states in transition that did not reach real democracy or even moved backwards enabled political scientists to review the concept of democratic transition and broaden it by adding a new necessary condition - democratic consolidation. So transformation means "(...) the transition from a centrally planned economy to a market economy involving a change in the political system and creating market conditions for the functioning of all economic entities" [14, p. 6].

As the history of international relations shows, what determines the position, place, and role of a state in the international order is its political system, its economic, scientific, and technical potential, its foreign policy, and many other factors that are decisive for its quality, attractiveness, and efficiency.

However, a more recent discussion done by scholars like Samuel Huntington (1991), Geoffrey Pridham (1991) or Lawrence Whitehead (2001) focused on the international aspects of democratization. These authors acknowledged that there were some international elements and dynamics that influenced the political process of the newborn democracies. Some of these elements involved pressure from great democratic powers (like the USA or the EU), international business, international trade among nations, and transnational values or ideas. Nevertheless, these scholars always stressed that the internal processes were more important and relevant to the democratization debate than the international phenomenon $[9 ; 13 ; 18]$.

There are many international dynamics that we could bring into the discussion. There are, for the importance of external conflicts or culture [9], the role of great powers"e pressure [18], or the importance of Western business, governments and NGOs [20].

Lawrence Whitehead distinguished three ways in which the international context was able to influence democratic processes: contagion, control and consent. The first formula predicted that democratization would advance spontaneously from country to country, mainly through the fluxes of information and communication exchanged between countries. The second hypothesis saw democratization expand in the form of pressure of one state towards another, through economic sanctions or support; and the last assumption through a convergence of goals between domestic and external actors [18, p. 3-25].

Some scholars indulged in studying the influence of the international context upon civil societies. Richard Youngs focused his research on Western influence over the new-born democracies from Eastern Europe, especially the USA and EU. In his study, he divided that Western influence in three groups: states, international business, and NGOs, and the relation of the last group with civil societies. Youngs said that the 1990s saw the rise of a denser and more plural global civil society, permeable to 
the new inflows of information and communication [20, p. 138]. Youngs stated that in Eastern Europe specifically, many NGOs (embedded in the Western values) were crucial in changing the mentalities and perceptions of the majority of the population, and in exporting the Western model of political and economic organization to the USSR, having later assisted some governments in policy-making activities and in structuring their new regimes [20, p. 137-144].

For our cases in particular, East-Central European countries, it is important to highlight the research of M. A. Vachudova "Europe Undivided: Democracy, Leverage, and Integration After Communism" (2005). In her study, she determined that the fall of communism was destined to creating complex puzzles about the relative importance of domestic and external factors in explaining policy and regime outcomes over time. The revolutions in East Central Europe were about emulating and joining the West. In a handful of states, these were extraordinary, joyful moments of regime change, with the leitmotif of the "return to Europe" carrying the day [16, p. 523].

Already in 1989 democratization was much more externally driven-by changes in Moscow and by inspiration from the West - than any of the existing theories expected. Scholars turned to explaining the hugely divergent political outcomes that followed the end of communist rule. By the mid1990s, this included studying the causal mechanisms that translated the actions and assistance of external actors into domestic political change.

After 1995, the EU exerted active leverage on the domestic politics of credible future members through the enlargement process. The benefits and requirements of EU membership, combined with the structure of the EU's pre-accession process, interacted with domestic factors to improve the quality of political competition and to accelerate political and economic reforms in candidate states. The enlargement of the EU has thus promoted a convergence towards liberal democracy across the region [15].

If we talk about Poland, many researchers point out that the greatest "transformation power" was in endogenous, specifically Polish factors that helped initiate the change process. However, they could have only begun to take effect after the collapse of the Soviet bloc, that is, the change of "boundary conditions". On the other hand, the collapse of communism and the opening of Poland to external influences allowed for the formation of the Polish transformation not only by endogenous factors, but also by global tendencies or external factors [19, p. 53-54].

Polish sociologist E. Wnuk-Lipiński proposed 5 transition stages: initial stage, intersystem stage, advanced stage, post revolutionary stage and consolidation stage. But he proposes a different explanation to the problem of transition [19, p. 56].

Initial phase means one in which processes characterized by "transformational power" are started. It is initiated by the emergence of an alternative to the old system, which has a real chance of entry into force. The author writes that the internal factors alone would not be enough to carry out a radical change of the one-party system. Only a clear change in external conditions triggered the internal strength of the country to overthrow the regime. Also, external factors alone are not enough to launch and carry out the first phase of radical change. Only a combination of internal and external factors is able to launch the discussed change.

It is also worth noting that initiating the first phase of radical social change does not mean that it will be fully realized. At this stage, it is not yet known whether the representatives of the former regime will take over or whether there will be a definite and lasting change [19, p. 57].

The intersystem phase began around 1990, as a result of the introduction of radical market reforms. It was characterized by a situation when the old rules were still working and the new ones were not clearly defined. Groups of interests are created, the aim of which is to achieve large profits in a short time using the unclear rules of the game.

The next phase called the advanced phase is characterized by the fact that the process of transition from "real socialism" to the democratic system exceeds the point beyond which there is no longer a return to the old system. The external stage also has an influence on the advanced phase of the transformation, as well as on the initial one. They may include the requirements of the International Monetary Fund, directed at the country's economic reforms. When the IMF's requirements are too 
strict, this may lead to social unrest, but when they are too "soft", they can contribute to the failure of a radical change and preservation of old group interests.

The post-revolutionary phase, initiated by the legal takeover of power by the post-communists, was characterized by an increase in support among the masses for stabilization. There is a definitive separation of legitimacy for the system from legitimization for a political party. It is worth noting that if this phase is prolonged, it increases the likelihood of a transformation failure. Even if the transformations are satisfactory, there is unfortunately a "hard restaurant" threat. Entering the postrevolutionary phase is just the beginning of building a new order and moving to the consolidation phase [19, p. 58].

\section{EFFECT OF EUROPEANIZATION IN THE PERIOD OF TRANSFORMATION}

Three levels of institutionalization of international connections can be specified, which are particularly important for research on post-communist transition, and at the same time differentiate the status of individual countries of Central and Eastern Europe.

The manifestation of such relations are:

a) participation in the European integration process, in particular association agreements with the European Union and relations with the Council of Europe;

b) membership in the Organization for Economic Cooperation and Development (OECD);

c) cooperation with the North Atlantic Treaty Organization (applying for membership in NATO) [10, p. 68].

The most important factor should be the transformation of the political and economic order subordinated to integration with the EU. For this reason, it can be described as "transformation through integration", because one of the main goals of all political forces has become the political slogan "return to Europe", based not only on similar institutional solutions, but on achieving full membership in the European Union. The researchers of transformation often distinguish in post-communist countries. [7, p. 104].

In addition, the membership was seen as a chance to consolidate the market economy and democratic institutions. Modernization through integration brought hope not only to facilitate the transformation process and to enter the next phase of modernization (mainly thanks to access to new markets and structural funds, as well as foreign investments and technologies), but also to Poland's finding itself in the processes of globalization.

We can conditionally divided transformations into a system transformation stage, which based on the market destruction of the old system with equally spontaneous creation of a new one and a "mixed" transformation stage, which was implemented "under the pressure of foreign institutions as a specific program to adapt the economic and political system to the standards of the European Union" [11, p. 76].

A feature of changes taking place after the collapse of the communist system is a very close relationship between the processes of systemic transformation and the institutionalization of international obligations, including in particular the process of enlargement of the European Union and NATO. The relationship between these processes is such that systemic changes have allowed to deepen and accelerate the process of new institutionalization of external relations, and at the same time have conditioned further transformation processes [10, p. 57].

However, it is worth pointing out some of the most characteristic elements of the post-communist transformation, which were related to external institutional requirements. First of all, modern political transformations were not of a holistic nature, contrary to the transformation taking place in the countries of Central and Eastern Europe. Poland and other post-communist countries believed that EU membership would be a sufficient remedy for all difficulties. This situation imposes the strategies of "modernization through internalization" for this region and increases their dependence on the actions of external actors (Western governments, international financial institutions, foreign investors, etc.). 
Systemic transformation in Central and Eastern Europe is the first attempt at the simultaneous transition to a market economy and liberal political democracy [1].

At the beginning of the 1990s, Poland signed the European agreement in which it expressed the will to integrate with the European Union. The association agreement did not provide Poland with any guarantee of future membership, it constituted the foundation for the further development of relations with the EC because it established an institutional and legal framework for long-term economic, political, social, and cultural cooperation.

The success of the "shock treatment" reform depended very much on the reaction of big state enterprises, on how fast and how deeply would they be able to adjust to the new situation. This proEuropean orientation emerges as one of the key sources of success, key engines for positive evolution of the system. Firstly, the association agreement, with all its acquis communautaire mobilized political will to reform, helped stem natural resistance to change, increased the level of policy discourse in the country. Secondly, intensified contacts with the EU provided a massive inflow of policy related knowhow. Last, but not the least, the association status finally (after some years of hesitation) resulted in a not insignificant increase inflow of FDI into Poland [1].

Poland has been frequently quoted as an example of successful reforms. High economic growth rates and general consistency of economic policy earned a reputation of one of the frontrunners in the process of transition. Both statistical data and political facts, such as Poland's admission to the OECD in 1996, NATO membership in 1999 and the EU accession in 2004, confirm this positive assessment.

\section{THE IMPACT OF FOREIGN INVESTMENT ON THE RESULT OF TRANSFORMATION}

Foreign direct investments are considered one of the main important elements of European integration and co-operation. Their beneficial aspects are especially important in countries in transition, like Poland, as they provide additional capital necessary to achieve the higher level of development. Also they are an important channel through which Poland gained access to better managerial and technological solutions [2, p. 78].

Foreign direct investment (FDI) has increased in the past twenty years, to become the most common type of capital flow needed for the reconstruction, stabilization of the CEE economies and economic growth. The volume of FDI inflows has grown rapidly, as the Governments of the CEE countries have officially encouraged FDI and developed a FDI promotion programs providing substantial incentives for foreign companies [17].

The transformation leaders have managed to obtain strong external support and attract considerable private capital. However, the flow of foreign capital to the countries of the region indicates that external capital was not so much the cause but rather the effect of successful reforms.

Poland is attracting for its foreign investments thanks to its successful stabilization program and a quick exit from the recession. The World Bank's report confirms this regularity: "official support of international financial institutions and assistance of individual countries are usually higher, in relation to the population or GDP, for those countries whose reforms are more advanced" [5, p. 512].

Since its transformation in 1989, Poland has been a very attractive country for foreign direct investors. Over the past years or so, PLN 666 billion has been invested in the country - PLN 27.7 billion a year on average. In the past century, foreign investment in Poland accelerated twice: in 1995-2000 and in 2004-2007. Immediately after the collapse of communism, companies from Western Europe and the US started investing in the country, mainly with the intention of satisfying consumer demand at a time when entry barriers. As the country joined the EU, it saw another wave of acquisitions, mergers and greenfield investments. It was also when foreign investors started to put more capital into the services sector, especially telecoms, financial companies and producers of machinery and other goods used by business. In 2016 the influx of FDI to Poland accelerated again. The biggest share of the new investments flowed from the USA, France and Germany [3, p. 9-11]. 


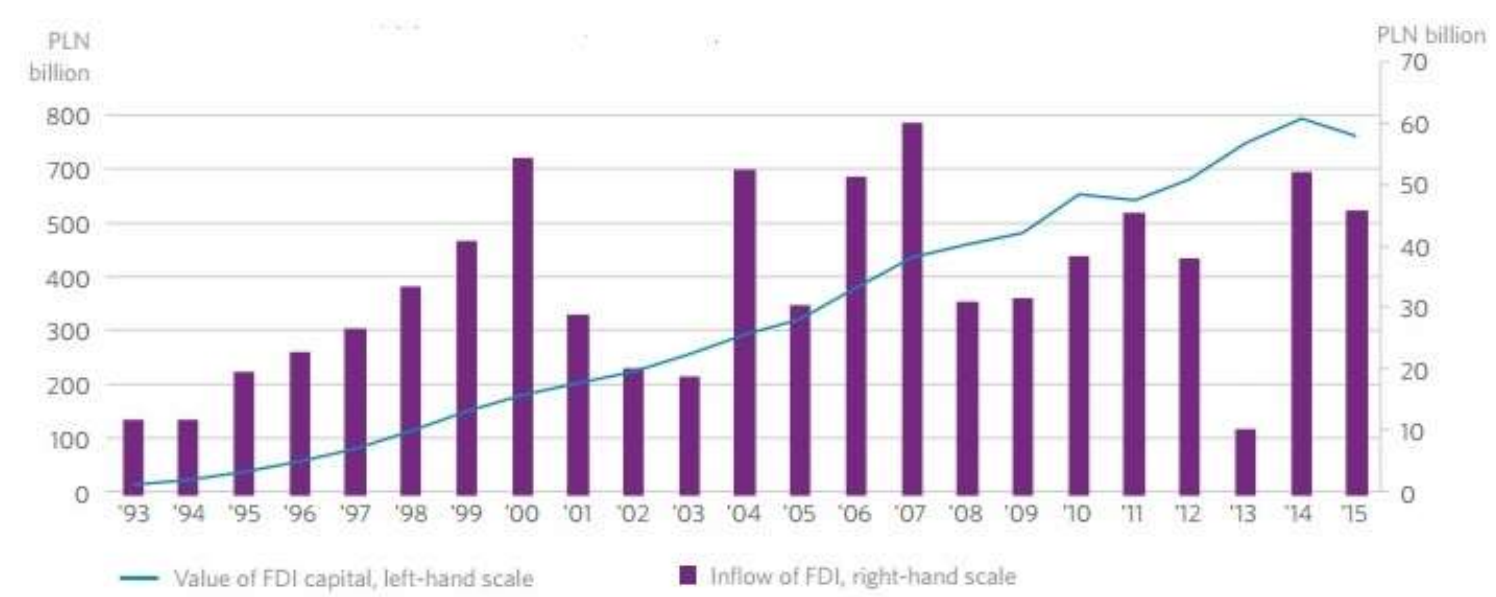

Fig. 1. How did the inflow of direct investment come to Poland (constant prices as of 2010) [3, p. 11].

\section{Issues Which Raise ARgument in Public Debate on System Transformation}

Membership in the EU has given Poland an opportunity to further develop, but this requires activeness on the part of Poland's elites and the development of strategy. The elites are not exempt from responsibility for the future of the country and should not pass all power to EU institutions. On the other hand, accession has caused Poland to follow certain fixed rules, which constitute a broad framework-not solely in the economic sense-for the country's development. Although Poland changed the context of its international alliances, it has not freed itself from peripheral status and this means that it has little influence on key decisions taken within the EU system of governance. There is a tension between the opportunities created by European integration and the limitations it imposes. Poland, like other EU member states, was given a historic chance to improve its international position, i.e., an opportunity to get promoted from the periphery to the so called semi-periphery of Europe [6, p. 9]. Membership in the European Union is not just a matter of foreign policy or the best option for financing economic modernization. Its importance is not limited to decisions on the abolition of customs borders and barriers to personal traffic. For the Polish society, the Union is primarily a comprehensive choice of civilization.

We can see the attitude of Polish society to the European Union. Acceptance of Poland's membership in the EU is almost universal today. In the Special Eurobarometer survey for the European Parliament of autumn $2018^{1}$, more than two thirds of EU citizens $(68 \%)$ believe that their country overall benefits from EU membership, the highest score since 1983; 87\% of Polish respondents think also that joining the European Union is beneficial for Poland [12].

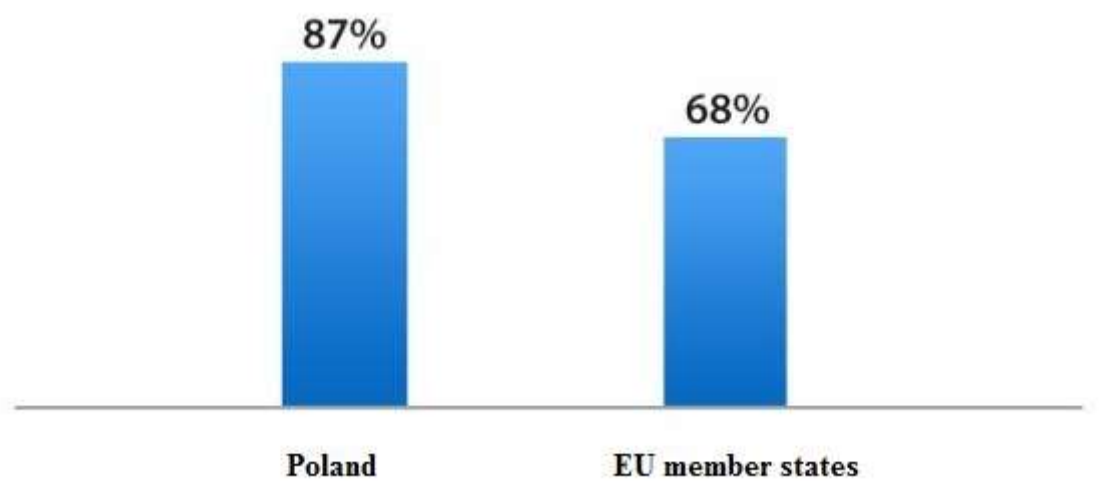

Fig. 2. Conviction about the benefits of belonging to the European Union [12].

\footnotetext{
${ }^{1}$ Background to the survey. The fieldwork of this survey was carried out between 8 and 26 September 2018 among 27474 Europeans aged 16 or more, interviewed face-to-face by Kantar Public in all 28 Member States.
} 
According to Polish respondents, Poland benefits from membership because the European Union contributes to economic growth in the country $(46 \%)$, provides Polish citizens with new employment opportunities (42\%) and improves standard of living (36\%). Also important for Poles are the EU role in maintaining peace and strengthening security $(19 \%)$ and the positive impact of EU membership on bilateral relations between Poland and other Member States (17\%) [12].

\section{CONCLUSIONS}

Therefore, both in the political and economic dimensions, external factors should be seen as modifiers of change, not as causative factors that produce specific effects. For example, the inflow of foreign direct investment should be considered as a result and not as a reason for successful economic reforms. Similarly, belonging to international organizations is almost always conditioned by meeting certain requirements. Countries seeking international acceptance and recognition first have to make efforts themselves to convert their economies to market and to democratize their political systems in order to be able to benefit from economic aid and political support later.

International integration accelerates the growth of productivity, trade, income, which in turn attracts foreign capital. Thus, expanding the impact of international factor on the one hand, directs states to the path of an open and liberal economy, on the other, imposes certain solutions in their domestic politics. Membership or promise of membership in international organizations facilitates the building of internal institutions and their adaptation to standards and laws applicable at the supranational level.

In general, international factors have played a key role in the democratization process in Central and Eastern Europe. They have had a decisive impact on all stages of change: deconstruction of the old regime, transfer of power and consolidation of the new institutional system. The international context of post-communist transformation consists of many different dimensions, including, among others, changing East-West relations, the collapse of the political and economic structures of the Soviet bloc, the formation of a new system of relations between the countries of Central and Eastern Europe. The entire range of international actors - states, international organizations, transnational social movements and non-governmental organizations, transnational corporations, multilateral financial institutions, etc. - plays peculiar roles, exerting influence on the course of events in post-communist countries.

\section{REFERENCES}

[1] Belka M. Lessons from Polish Transition. Lessons and challenges in transition. Conference Hall of the Czech National Bank, 22 September 2000. Available at: http://www.cnb.cz/cs/verejnost/pro_media/konference_projevy/konference/download/mmf_belka.pdf

[2] Clausing K., Dorobantu C. Re-entering Europe: does European Union candidacy boost foreign direct investment? Economics of Transition, 13 (1) (2005), 77-103. doi: 10.1111/j.1468-0351.2005.00208.x

[3] Czerniak A., Blauth K. The impact of Foreign Direct Investment. Contribution to the Polish economy in the past quarter century. Polityka Insight, Warszawa, 2017.

[4] Dudek A. The Consequence of the System Transformation of 1989 in Poland. European Remembrance Symposium, 2012-16. Publication (2015). Available at: http://www.enrs.eu/sk/articles/1516-theconsequence-of-the-system-transformation-of-1989-in-poland

[5] Ekiert G. Prawidłowości transformacji w Europie Wschodniej. Studia Socjologiczne, 1 (200) (2011), 501526. (in Polish)

[6] Fiszer J.M. From Political Transformation to Europeanization and Democracy in the New European Union Member States: An Attempt to Review Results. Polish Sociological Review, 3 (195) (2016), 373-388. 
[7] Fiszer J.M. Efekty transformacji ustrojowej i integracji państw Europy Środkowo-Wschodniej z Unią Europejską. Myśl Ekonomiczna i Polityczna, 2 (53) (2016), 97-124. (in Polish)

[8] Rodrigo Gomes Quintas da Silva. Democracy, civil society, and the importance of the international context: the cases of Poland and Czechoslovakia. 2016. Available at: https://repositorio.iscteiul.pt/bitstream/10071/12601/1/Disserta\%C3\%A7\%C3\%A3o\%20de\%20Mestrado.pdf

[9] Huntigton P.S. Democracy's Third Wave. Journal of Democracy, 2 (2) (1991), 12-34.

[10] Jasiecki K. Wpływ instytucjonalizacji powiązań międzynarodowych na procesy transformacji ustrojowej w Europie Środkowej i Wschodniej. Studia Europejskie / Centrum Europejskie Uniwersytetu Warszawskiego, 1 (1997), 57-72. (in Polish)

[11] Lubbe A. Transformacja, modernizacja czy po prostu normalizacja? W: Morawski W. (red.) Modernizacja Polski. Struktury, agencje, instytucje. Wydawnictwa Akademickie i Profesjonalne, Warszawa, 2010. (in Polish)

[12] Parlametr 2018 - Podjęcie Wyzwania: Od (Cichego) Poparcia Do Udziału W Wyborach. Available at: http://www.europarl.europa.eu/at-your-service/pl/be-heard/eurobarometer/parlemeter-2018-taking-upthe-challenge (in Polish)

[13] International influences and democratic transition: problems of theory and practice in linkage politics. In: Pridham G. (Ed.) Encouraging Democracy: The International Context of Regime Transition in Southern Europe. St. Martin's Press, New York, 1991, 1-28.

[14] Prohnitchi E. Comparative analysis of the modes of transition in Hungary and Poland and their impact on the electoral systems of these states. CEU Political Science Journal. The Graduate Student Review, 1 (3) (2006), 5-10.

[15] Vachudova M.A. Europe Undivided: Democracy, Leverage, and Integration after Communism. Oxford University Press, Oxford, 2005. doi: 10.1093/0199241198.001.0001

[16] Vachudova M.A. External Actors and Regime Change: How Post-Communism Transformed Comparative Politics. East European Politics and Societies: and Culture, 29 (2) (2015), 519-530. doi: $10.1177 / 0888325415571411$

[17] Vaknin S. Eastward, Ho - Global Recession and Foreign Direct Investment (FDI) in Central and Eastern Europe (CEE). UPI, 2007. Available at: http://samvak.tripod.com/brief-fdicee01.html

[18] Whitehead L. Democracy and Decolonization: East-Central Europe. In: Whitehead L. (Ed.) The International Dimensions of Democratization: Europe and the Americas. New York, Oxford University Press, 2001. doi: 10.1093/0199243751.003.0013

[19] Wnuk-Lipiński E. Zmiana systemowa. W: Wnuk-Lipiński E., Ziółkowski M. (Red.) Pierwsza dekada niepodległości. Próba socjologicznej syntezy. Instytut Studiów Politycznych Polskiej Akademii Nauk, Warszawa, 2001, 21. (in Polish)

[20] Youngs R. International Democracy and the West: The Role of Governments, Civil Society and Multinational Business. Oxford University Press, Oxford, 2004. doi: 10.1093/0199274460.001.0001

Address: Nataliia Holubiak, Vasyl Stefanyk Precarpathian National University, 57, Shevchenko Str., IvanoFrankivsk, 76025, Ukraine.

E-mail: holubiakn@gmail.com

Received: 21.08.2018; revised: 12.12.2018.

Голуб'як Наталія. Зовнішні фактори системної трансформації в Польщі. Журнал Прикарпатського університету імені Василя Стефаника, 5 (3-4) (2018), 16-24.

Проаналізовано нову перспективу процесів демократизації шляхом аналізу ролі зовнішньої динаміки трансформації Польщі. Академічні дослідження лише зовсім недавно почали 
зосереджуватися на зовнішніх факторах трансформації, натомість переважали акценти щодо курсу політичних еліт та діяльності інституцій. У першій частині статті розглядаються теоретичні основи трансформації, які поєднують зовнішні та внутрішні чинників перетворень в Центральній та Східній Європі. Для прикладу використана модель польського дослідника Едмунда Внука-Діпінського, який розробляе послідовність п'яти фаз переходу від старої системи до нової в Польщі. У наступній частині описується етап “трансформації через інтеграцію” та аналізуються наслідки накладання процесів системного перетворення на процеси вступу до Євросоюзу. Підсумовується значення членства в ЄС як можливості подальшого розвитку, фактору збільшення прямих іноземних інвестицій та цивілізаційного вибору польського суспільства.

Ключові слова: трансформація, вступ до ЄС, інтеграція. 